\title{
COUNSELING ABOUT THE ACCOUNTING PROFESSION AND THE IMPORTANCE OF FINANCIAL STATEMENTS AS A FORM OF ACCOUNTABILITY FOR STAKEHOLDERS ON STUDENTS OF SMKN 2 TANGERANG SELATAN
}

\author{
Hari SETIYAWATI', Muhyarsyah MUHYARSYAH ${ }^{2}$, Salmi Mohd ISA ${ }^{3}$, \\ Yuvaraj A/L GANESAN ${ }^{4}$ and Ooi Say KEAT ${ }^{5}$ \\ ${ }^{1,2}$ Universitas Mercu Buana \\ 3,4,5 University Sains Malaysia \\ 'hari_setiyawati@mercubuana.ac.id; ${ }^{2}$ muhyarsyah@mercubuana.ac.id; ${ }^{3}$ salmi.mohd.isa@usm.my \\ 4yuvaraj@usm.my; ${ }^{5}$ ooisaykeat@usm.my
}

\begin{abstract}
This community service is carried out in foreign cooperation where the partner is Professor Dr. Salmi Mohd Isa, Yuvaraj A/ L Ganesan, Ooi Say Keat, Ph.D from the Graduate School of Business, University Sains Malaysia. We give this community service activity with the theme "Counseling on the Accounting Profession and the Importance of Financial Reports as a Form of Accountability for Stakeholders in Students of SMKN 2 Tangerang Selatan. The target of this activity is students of class XII. They were given material explanations about the accounting profession, what accounting is and how it processes, preparation of financial reports, the use of financial reports, accountability and stakeholders. The implementation will be carried out in a Vicon fashion in the form of a Webinar around February 2021 (In Syaa Allah). Participants will be given material modules and certificates as well as internet credit money reimbursements. The results of the expected activities are that the student participants of SMKN 2 Tangerang Selatan gain an understanding of the accounting profession, what accounting is, how to record transactions to compile financial reports to how accountable they are to stakeholders. So that students of SMKKN 2 South Tangerang understand very well about the accounting profession and can determine their choice of fields for further study or work and if they choose the field of accounting then understand the importance of financial reports as a form of accountability for stakeholders. Evaluation can be done by looking for information at graduation through the counseling guidance teacher and the homeroom teacher regarding the plans of the students.
\end{abstract}

Keywords : The Accounting Profession, The Financial Statements and Accountability

\section{BACKGROUND}

SMK Negeri 2 Kota Tangerang Selatan was founded in 2008, with its initial name being SMK Negeri 8 Pondok Aren. Then with the regional expansion, part of Tangerang Regency became South Tangerang City, SMKN 8 Pondok Aren which was included in the area of South Tangerang City, changed to SMK Negeri 2 South Tangerang City. The vision of SMKN 2 Tangerang Selatan is: To become a quality, superior vocational school based on IMTAQ and science and technology and to produce graduates who are able to compete at the national and global levels. Meanwhile, the missions of SMKN 2 Tangerang Selatan are: 1) Improving the quality of school organization and management in fostering a spirit of excellence and competitiveness; 2) Improving the quality of teaching and learning activities in achieving national / international standard student competencies; 3) Improving the quality of competence of teachers and employees in realizing minimum service standards (SPM); 4) Increasing the quantity and quality of educational facilities and infrastructure in support of mastery of science and technology; 5) Improve the quality of human resources and the quality of student coaching in realizing IMTAQ and an attitude of independence; 6) Increase partnerships with DU / DI according to the demand driven principle; 7) Improve the quality of production unit management to support the quality of human resources; 8) Empowering the school environment in realizing wiyata mandala insights. The objectives of SMKN 2 Tangerang Selatan are: 1) Preparing students to become productive human beings capable of working independently, filling job vacancies in the business world and industry as middle-level workers according to the competence in the expertise program they choose; 2) Prepare students to be able to choose careers, be resilient and persistent in competing, adapt to the work environment, and develop a professional attitude in the area of expertise they are interested in; 3) Equipping students with science, technology and art, in order to be able to develop themselves in the future both independently and through higher education levels; 4) Equip students with competencies that are in accordance with the chosen expertise program. The facilities \& infrastructure owned include: Owned buildings, comfortable and spacious classrooms, 3 rooms of computer laboratories, 1 language laboratory, workshop with complete equipment, library, prayer room, large sports field, large parking area, cooperative, studio Music.

SMKN 2 Tangerang Selatan is one of the partners of Mercu Buana University. The exact location is on Jl. Raya Pondok Aren No.52 Pondok Aren, Pondok Aren District, South Tangerang City, Banten 15224, about $10 \mathrm{KM}$ from the Mercu Buana University campus. The number of students currently is more than 1000 students. Since the launch of the concept of School Based Quality Improvement Management in the school management system, the School Committee as a school partner organization has a very strategic role in the effort to participate in developing education in schools. Its presence is not just a school stamp, especially in an effort to collect fees from parents of students, but further the School 
Committee must be able to become an organization that can truly accommodate and channel the aspirations and initiatives of the community in producing operational policies and educational programs in schools and can create a transparent, accountable and democratic atmosphere and conditions in the delivery and quality of education services in schools.

This Community Service activity that we organize is in order to achieve the first mission, which is to foster a spirit of excellence and competitiveness, also in order to achieve the second and third goals, namely preparing students to be able to choose careers, be resilient and persistent in competing, adapting to the work environment and develop a professional attitude in the field of expertise they are interested in and equip students with science, technology and art, so that they are able to develop themselves in the future both independently and through higher education levels.

The accounting profession is a profession that is classified as rare, meaning that the need for labor in accounting is still far greater than the number of job seekers with accounting education. So that there is no misunderstanding, especially about the accounting profession, its duties and responsibilities, it is necessary to have early outreach and counseling about accounting education and the accounting profession, so that it can be seen what the actual role of accountants is. In addition, it also requires an understanding of what accounting products are, namely financial reports and how important financial reports are as a form of accountability for stakeholders. Through this early socialization, it is hoped that it can awaken the interest of high school students early to study at the Accounting Study Program who will later become a bachelor of accounting and later become accountants. Through this counseling, it will be explained about what Education / Accounting Study Program is, what requirements are needed to enter the Study Program, what job opportunities can be entered by students in the future related to this study program. Based on the background mentioned above, it can be formulated the following problems:

a. What is the accounting profession and how do you achieve it?

b. What is meant by accounting and how is the process of preparing financial statements?

c. How important are financial reports as a form of accountability to stakeholders?

\section{Solutions And Outcome Targets}

Based on the problems described in the situation analysis above, the solution that will be carried out is to provide provision to students of SMKN 2 Tangerang Selatan and instill understanding in these students, especially those who are interested in becoming accountants. The provision given was in the form of counseling about what the accounting profession is, how the role of accountants in the company, what are the areas of accounting work, the process of preparing financial reports and the importance of financial reports as a form of accountability to stakeholders. Also instilled in ethics, morals and an objective mental attitude so that later when they become accountants they are accustomed to upholding the code of ethics so that they do not record fictitious transactions. If the cultivation of this mental attitude is successful, it will reduce the level of corruption in Indonesia. The target output expected from this activity is that students of SMKN 2 Tangerang Selatan can understand the accounting profession and improve skills related to accounting.

\section{METHOD}

The target of this activity is students of class XII SMKN 2 Tangerang Selatan, which is a school partnering with Universitas Mercu Buana located approximately $10 \mathrm{KM}$ from the Mercubuana University campus. The implementation method used in this activity is to provide counseling in the form of visual conferences / Vicon / Webinars because the conditions in the Jakarta and Banten areas are still pandemic. Students are given facilities for Vicon in the form of replacing internet credit. The event begins with a speech from PPM Partners, namely Professor Dr. Salmi Mohd Isa from the Graduate School of Business, University Sains Malaysia. The trainer was the PPM team from Mercu Buana University.

The materials that will be provided are:

1. Introduction to accounting and the accounting profession.

2. The process of preparing financial reports

3. The importance of financial reports as a form of accountability to stakeholders.

4. Evaluation

This Community Service activity that we hold aims to achieve one of the missions of SMKN 2 Tangerang Selatan, namely to foster a spirit of excellence and competitiveness, as well as to prepare students to be able to choose careers, be tenacious and persistent in competing, adapt to the work environment, and develop professional attitudes in the area of expertise that he is interested in as well as equipping students with science, technology and art, in order to be able to develop themselves in the future either independently or through higher education levels. Achieving these objectives is done by providing training through counseling about what the accounting profession is, how the role of accountants in the company, what are the areas of accounting work, the process of preparing financial reports and the importance of financial reports as a form of accountability to stakeholders.

The benefit of this activity is so that students of SMKN 2 Tangerang Selatan gain an understanding of the accounting profession, what accounting is, how to 
record transactions to compile financial reports to how accountable they are to stakeholders. So that students of SMKN 2 Tangerang Selatan understand the accounting profession and can determine their choice offield for further study or work and if they choose the field of accounting then they understand the importance of financial reports as a form of accountability for stakeholders. Also instilled in ethics, morals and an objective mental attitude so that later when they become accountants they are accustomed to upholding the code of ethics so that they do not record fictitious transactions.

The accountant profession is all fields of work that employ expertise in the field of accounting, including public accountants, internal accountants who work for industrial, financial or commercial companies, accountants who work in government, and accountants as educators. The accountant profession is a unique profession in which this profession has a vital role and responsibility, some of which play a role in the process of preparing corporate financial reports so as to attract investors to invest in the company and provide an opinion on the fairness of these financial statements. can be separated from the development of accounting professionals that foster the accounting profession that is born from the contribution of the world of higher education (universities) and professional organizations. The accounting profession in Indonesia has only developed since the issuance of Law No. 34, 1954 concerning the right to public practice and the use of accreditation of accounting degrees.

Accounting is the recording, identification, measurement, reporting and communication of financial information about economic entities to interested users. According to Kieso, Weygant, and Warfield (2014: 4) accounting is: "Accounting is an information system that identifies, records, and communicates the economic events of an organization to interested users". In the last 30 years economic entities have changed significantly in terms of both size and complexity and the users concerned have also increased substantially in both number and variety. That is, the responsibility borne by the accounting profession today is greater than before. In general, this accounting cycle starts from transaction activities to financial reports. Although there are many types of financial reports, the Financial Accounting Standards (SAK) state that the main financial statements only consist of balance statements, profit / loss statements, cash flow statements, and notes to financial statements. Financial Accounting Standards (SAK) are guidelines that contain the principles and rules for preparing financial statements so that financial reports can be relied on for decision making.

Accountability according to Mardiasmo (2018) is accountability to the public for every activity carried out. Meanwhile, according to Penny (2014) Accountability is a form of obligation for providers of public activity to be able to explain and answer all matters concerning the steps of all decisions and processes taken, as well as accountability for their results and performance. Based on this understanding, it can be concluded that accountability is a form of obligation to submit reports or accountability to interested parties either by a person or a group of people (organizations) who have received mandates from other parties. Mardiasmo (2018) Public accountability is the obligation of the mandate holder to provide accountability, present, report and disclose all activities that are their responsibility to the trustee who has the right and authority to hold this accountable. If the components of the financial statements are complete, submitted according to deadlines, and audited by an external institution, the preparation of annual financial reports is accountable and transparent (Puspita and Amin, 2020). Evaluation is intended to measure whether there are significant differences in knowledge of accounting and its profession and its relationship to accountability before and after counseling is carried out. Therefore, evaluation is carried out by providing a questionnaire before extension is carried out and after counseling is carried out. Evaluation can be done by looking for information at graduation through the counseling guidance teacher and the homeroom teacher regarding the plans of the students.

\section{RESULTS AND DISCUSSIONS}

This community service activity was carried out on February 2, 2021 by means of a Webinar using the Zoom Meeting which was attended by 81 students of SMKN 2 South Tangerang and three teachers. This community service activity results in increased knowledge and understanding of the accounting profession, the accounting cycle, financial reporting and accountability for stakeholders. Insyaa Allah participants can understand the material presented by the team which is presented through Zoom. Training participants are evaluated in the last session, namely by conducting a test on the material that has been delivered. The participants were very enthusiastic in participating in this training, and gave a positive response, this can be seen from the impression that the message was filled in in the questionnaire form via googleform.

The webinar event starts at 08.30 beginning with participant registration. Dr. Lin Oktris, who acts as the MC, opens the event at 09.00. Head of Master of Accounting Study Program Dr. Hari Setiyawati, who was the team leader in this activity, officially opened the event, besides that he also acted as a presenter and resource person. Dr. Salmi Mohd.Isa, who is a partner in this activity, acted as a keynotes speaker presenting material related to integrity for youth. The material presented was so interesting that many questions were asked during the discussion session which was guided by Mrs. Maryam Chairunisa, M.Ak as the moderator. Various questions were asked either via chat or asking directly. Questions related to the material presented, namely about the accounting profession, Financial Accounting Standards, financial reports, 
integrity and governance. All questions were answered directly by the resource person, namely the team leader in this activity and the keynotes speaker. The event ended with the display of the certificate on the screen. Do not forget that participants are also asked to fill in attendance via google form and also fill out a questionnaire to evaluate this activity via google form.

\section{CONCLUSIONS AND SUGGESTIONS}

The accountant profession is a profession that is still very much needed by the community. Many participants did not understand what the accounting profession is and how to get it. The team answered various questions about this very well. Many participants who are interested in continuing their studies in accounting courses so they can become accountants. The participants were very enthusiastic about this activity and they really hope that this activity will continue and be repeated again. This can be seen from the impression messages written through the questionnaire. Participants are expected to benefit from this Community Service Program. These benefits include knowledge and understanding of the accounting profession, accounting standards, financial reporting, integrity and governance. Where this knowledge is very useful for their provision after graduation, both to continue to the tertiary level or to work immediately. Counseling through this webinar is very useful for students of SMKN 2 Tangerang Selatan in terms of preparing themselves to continue their studies in the Accounting major or who will work directly in companies, considering that integrity is also the basic asset for youth in every activity.

The accounting profession establishes integrity in the implementation of accountant professionalism, is consistent and steadfast in upholding noble values and beliefs. Consistent between actions with values and principles, Integrity must start from each person and start from oneself not blaming others but more trying to improve oneself from wrong actions. Integrity will not be able to be implemented if it is not carried out together because of mistakes made by others without warning and correction from those who see wrong actions will result in a culture of justification because mistakes can be considered as the truth, therefore integrity is a shared responsibility. High integrity is a strong foundation in achieving excellence.

Participants suggested that Community Service activities like this should be held more frequently because they are very useful both in knowledge and application. Lots of suggestions and suggestions from similar participants as presented above. They hope that the same webinar will also be held next year.

\section{REFERENCES}

Dahlia, Nurhidayah, dan Nurul Listiawati. 2019. Analisis Akuntabilitas Dan Transparansi Laporan Keuangan Partai Politik (Studi Kasus Pada Masyarakat Kecamatan Banggae Kabupaten Majene). Sebatik 2621-069X p 292-300

Ikatan Akuntan Indonesia. 2018. Standar Akuntansi Keuangan. Salemba Empat

Mardiasmo. 2018. Akuntansi Sektor Publik. Yogyakarta : Andi

Penny, L K. 2014. Membumikan Transparansi Dan Akuntabilitas Kinerja Sektor Publik: Tantangan Demokrasi Ke Depan. Jakarta. : PT Gramedia Widiasarana Indonesia :

Puspita Dewi Wulaningrum \& Amin Pinanto. 2020. Akuntabilitas dan Transparansi Laporan Keuangan Pada Organisasi Pengelola Zakat: Studi Komparatif di BAZ dan LAZ Yogyakarta. Jurnal Akuntansi Terapan Indonesia, Vol 03 No 1 Hal 15-24 March 2020.

Tuanakotta, Theodorus M, Setengah Abad Profesi Akuntansi, Seri Departemen Akuntansi FEUI, Penerbit Salemba Empat, 2007

Undang -Undang No. 34 Tahun 1954 Tentang Pemakaian Gelar Akuntan.

Warren, Reeve and Duchac. 2014. Accounting, 16 Edition. Thomson

https://smkn2tangsel.sch.id/html/index.php

\section{PICTURE}
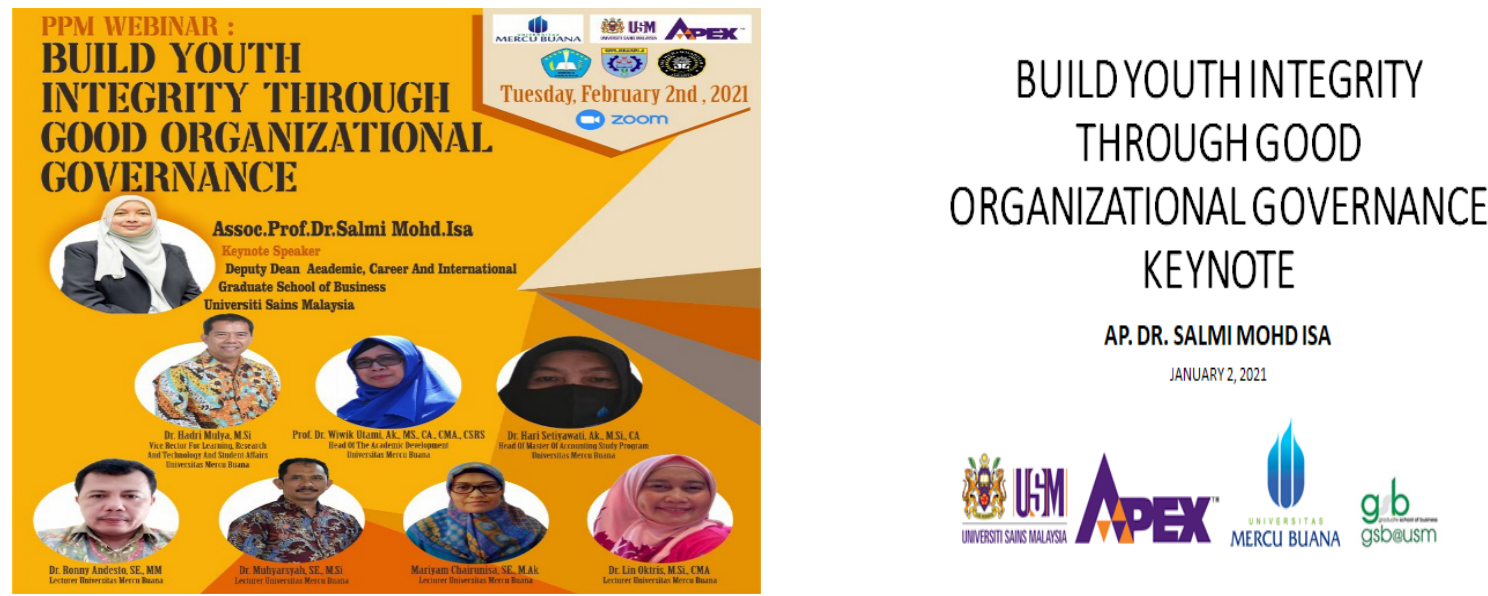

Community Empowerment In Tourism \& Creative Economy 
Organizational

Governance

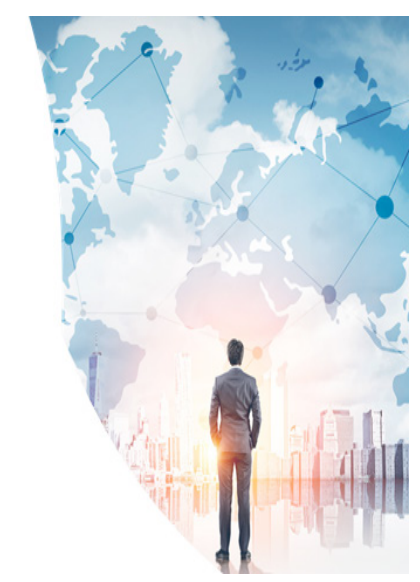

Integrity starts with

yourself

Good governance?

Bad governance?

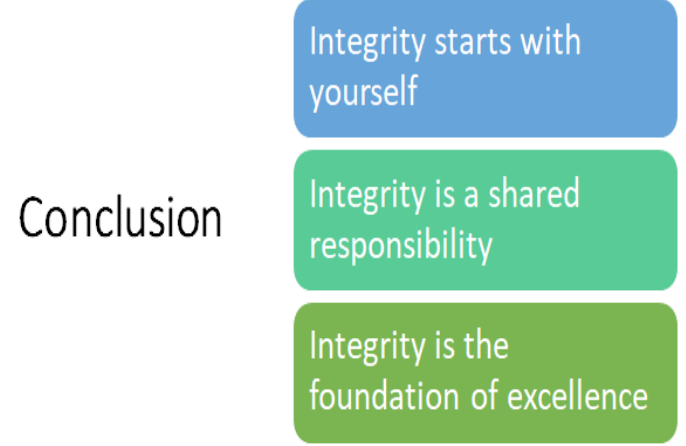

LAW ENFORCEMENT OFFICERS
'Enforce the law without fear or favour'

Corruption
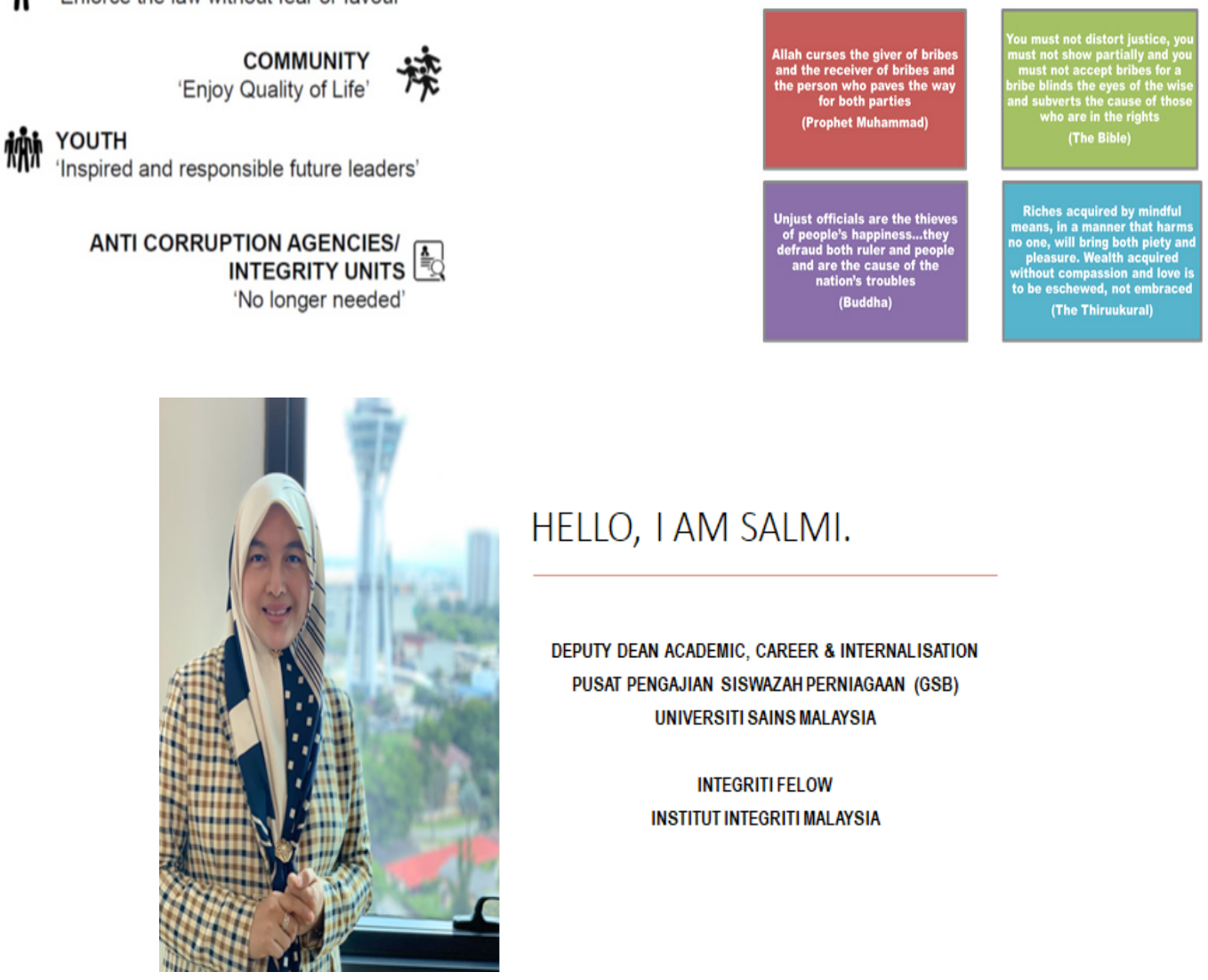

HELLO, I AM SALMI.

DEPUTY DEAN ACADEMIC, CAREER \& INTERNALISATION

PUSAT PENGAJIAN SISWAZAH PERNIAGAAN (GSB)

UNIVERSITI SAINS MALAYSIA

INTEGRITIFELOW

INSTITUT INTEGRITI MALAYSIA 